\title{
PENGARUH MODEL PEMBELAJARAN KOOPERATIF TIPE STAD MENGGUNAKAN MEDIA FILM ANIMASI TERHADAP MOTIVASI DAN HASIL BELAJAR SISWA DI MTS. AL-INTISHOR SEKARBELA
}

\author{
Bahtiar ${ }^{1}$, Muhammad Kafrawi ${ }^{11}$, Sri Yeni ${ }^{1)}$ \\ 1) Program Studi Tadris Fisika Universitas Islam Negeri Mataram, Matyaram, NTB, Indonesia \\ Corresponding author : Bahtiar \\ E-mail : bahtiar79@uinmataram.ac.id
}

Diterima 08 September 2020, Direvisi 01 November 2020, Disetujui 02 November 2020

\begin{abstract}
ABSTRAK
Penelitian ini bertujuan untuk mengetahui pengaruh model pembelajaran kooperatif tipe STAD menggunakan media film animasi terhadap motivasi dan hasil belajar siswa di MTs. Al-Intishor Sekarbela. Jenis penelitian ini adalah penelitian quasi eksperiment dengan desain penelitian nonequivalent control group design. Populasi penelitian ini adalah seluruh siswa MTs. Al-Intishor Sekarbela dengan sampel penelitian siswa kelas VII-A sebagai kelas eksperimen dan kelas VII-B sebagai kelas kontrol. Penentuan sampel dilakukan dengan teknik cluster sampling. Teknik pengumpulan data adalah menggunakan angket untuk memperoleh motivasi belajar dan tes subjektif untuk memperoleh hasil belajar. Berdasarkan hasil analisis data motivasi sesudah perlakuan diperoleh nilai rata-rata kelas eksperimen sebesar 2.86 dan kelas kontrol 2.29, sedangkan untuk analisis data hasil belajar menggunakan uji-t diperoleh $t_{\text {hitung }}(9.633)>t_{\text {tabel }}$ (1.703). Jadi, dalam penelitian ini dapat disimpulkan bahwa terdapat pengaruh model pembelajaran kooperatif tipe STAD menggunakan media film animasi terhadap motivasi dan hasil belajar di MTs. Al-Intishor Sekarbela.
\end{abstract}

Kata Kunci: kooperatif tipe STAD; media film animasi.

\begin{abstract}
This study aims to determine the effect of cooperative learning model type STAD using animated film media on student motivation and learning outcomes in MTs. Al-Intishor Sekarbela. This type of research is a quasi-experimental research design with a nonequivalent control group design. The population of this study were all MTs students. Al-Intishor Sekarbela with the research sample of class VII-A students as the experimental class and class VII-B as the control class. The sample was determined by using cluster sampling technique. Data collection techniques are using questionnaires to obtain learning motivation and subjective tests to obtain learning outcomes. Based on the results of the analysis of the motivation data after the treatment, the average value of the experimental class was 2.86 and the control class was 2.29, while for the analysis of the learning outcomes data using the t-test, it was obtained tes $(9,633)>$ table $(1.703)$. So, in this study it can be concluded that there is an effect of the STAD cooperative learning model using animated film media on motivation and learning outcomes in MTs. Al-Intishor Sekarbela.
\end{abstract}

Keywords: cooperative type STAD; animation film media.

\section{PENDAHULUAN}

Pendidikan merupakan salah satu upaya untuk mengembangkan kualitas SDM yang pada umumnya wajib dilaksanakan oleh setiap warga negara. Pendidikan yaitu program strategis jangka panjang yang pada penyelenggaraan harus mampu menjawab kebutuhan serta tantangan secara nasional(Ansori, 2015; Fujiawati, 2016). Pendidikan juga merupakan upaya sadar orang dewasa (terencana ataupun tidak), bertujuan untuk mewujudkan peserta didik secara aktif, mengembanngkan potensi dirinya guna memiliki kemampuan kecerdasan (intelektual, emosional, dan spiritual), berupaya membentuk akhlak mulia dan menumbuhkan keterampilanketerampilan yang diperlukan, baik untuk dirinya, masyarakat, ataupun lingkungan dimana mereka berada (Laela NRK. dan Partono, 2015)

Pada hakekatnya kegiatan belajar mengajar adalah suatu proses interaksi atau hubungan timbal balik antara guru dan siswa dalam satuan pembelajaran. Guru sebagai salah satu komponen dalam proses belajar mengajar merupakan pemegang peran yang sangat penting. Guru bukan hanya sekedar menyampaikan materi saja, tetapi lebih dari itu 
guru sebagai fasilitator dan motivator dalam pembelajaran (Rivai, 2019). Belajar juga merupakan kegiatan atau suatu proses usaha yang dilakukan oleh seseorang untuk memperoleh suatu perubahan yang baru sebagai hasil pengalamannya sendiri dalam interaksi dengan lingkungannya (Zakiah \& Kusmanto, 2017).

Keberhasilan proses belajar dipengaruhi oleh banyak faktor, salah satunya adalah strategi belajar mengajar yang digunakan oleh guru. Guru memiliki peran penting dalam menentukan kualitas dan kuantitas pengajaran yang dilaksanakannya. Oleh sebab itu, guru harus membuat perencanaan dalam meningkatkan hasil belajar siswa dan memperbaiki kualitas mengajarnya. Guru yang inovatif dan kreatif berani mencoba metode dan strategi baru yang dapat membantu meningkatkan motivasi siswa untuk belajar, agar siswa dapat belajar dengan baik maka metode mengajar yang digunakan harus tepat, efisien, efektif, dan sekreatif mungkin (Zakiah \& Kusmanto, 2017).

Adanya motivasi yang tinggi dari siswa diharapkan mampu menggerakkan minat siswa untuk menjadikan sekolah bukan hanya sebagai tuntutan namun juga merupakan kebutuhan bagi dirinya. Dalam belajar diperlukan adanyan motivasi. Hasil belajar akan menjadi optimal kalau ada motivasi. Makin tepat motivasi yang diberikan, akan makin berhasil pula pelajaran itu. Jadi dapat dikatakan motivasi akan senantiasa menentukan intensitas usaha belajar bagi para siswa sehingga hasil belajar siswa akan semakin meningkat (Palupi, Anitah, \& Budiyono, 2014).

Pembelajaran fisika merupakan suatu proses belajar mengajar yang dibangun oleh guru untuk mengembangkan kemampuan memahami konsep, prinsip, maupun hukumhukum fisika sehingga dalam proses pembelajarannya harus mempertimbangkan strategi atau model pembelajaran yang efektif dan efisien (Hanna, Sutarto, \& Harijanto, 2016).

Kebanyakan dari pembelajaran fisika hanya menekankan pada aspek penguasaan konsep, sehingga menyebabkan peserta didik menjadi pasif dan kurangnya pelaksanaan latihan keterampilan. Sebagian besar pembelajaran fisika dilakukan dengan model pengajaran konvensional yaitu dengan ceramah, sehingga peserta didik menjadi bosan, kurang tertarik untuk mengikuti pembelajaran, kurang aktif dalam pembelajaran, serta kurang terbangunnya sikap kerjasama antar peserta didik.

Berdasarkan hasil observasi dan wawancara dengan guru mata pelajaran bahwa hasil belajar siswa masih dibawah standar kriteria ketuntasan minimal (KKM) yang harus dicapai yaitu 70. Rendahnya hasil belajar ini disebabkan guru masih menggunakan pembelajaran konvensional dan kurangnya motivasi belajar siswa, selain itu di karenakan keterbatasan media maupun sarana yang memadai. Sehingga proses belajar mengajar menjadi kurang menarik. Selain itu, guru lebih mengacu pada penyampaian penghabisan materi dan mengabaikan penggunaan media ataupun metode yang sesuai dengan materi. Padahal, penggunan media ataupun metode yang sesuai dengan materi merupakan salah satu faktor yang dapat membangkitkan motivasi serta mengoptimalkan hasil belajar siswa.

Perbaikan hasil belajar dapat dicapai melalui peningkatan pemahaman siswa terhadap konsep materi ajar yang diberikan dan juga disertai keaktifan siswa pada saat proses pembelajaran. Banyak faktor yang mempengaruhi hasil belajar siswa, salah satunya adalah model pembelajaran. Model pembelajaran diperlukan untuk mendukung terjadinya proses pembelajaran yang aktif dan interaktif antara siswa dan guru. Salah satu diantara model pembelajaran adalah model pembelajaran kooperatif (Gilang Herjuna, Sanjaya, 2017). Oleh karena itu untuk meningkatkan hasil belajar fisika serta untuk menumbuhkan sikap kerjasama yang optimal maka dipilihlah model pembelajaran kooperatif. Sejauh ini masih banyak guru yang memakai media papan tulis dalam pembelajaran yang biasanya akan membuat siswa merasa bosan dan jenuh, padahal ada beberapa media yang lebih menarik dan mudah untuk diterapkan yaitu salah satunya dengan media film animasi. Media film animasi merupakan salah satu bahan ajar audio-visual yang dapat diterapkan dalam kegiatan pembelajaran. Bahan ajar audio-visual adalah bahan ajar yang menggabungkan kemampuan audio dan dilengkapi sajian berupa visual (gambar bergerak) (Zakirman \& Hidayati, 2017).

Penggunaan media film animasi dalam pembelajaran memberikan suasana yang baru dan menyenangkan bagi siswa serta dapat meningkatkan minat dan motivasi siswa dalam belajar. Pemanfaatan media film animasi dalam proses pembelajaran dapat meningkatkan kualitas proses dan hasil belajar, karena film animasi bersifat menarik. Jika media film animasi ini sudah menarik perhatian siswa, maka diharapkan informasi akan mudah dimengerti, karena sebanyak mungkin indera terlibat, terutama telinga dan mata yang digunakan untuk menyerap informasi (Hasanah \& Nulhakim, 2015). 
Penggunaan media pembelajaran film animasi dapat dikombinasikan dengan model pembelajaran yang sesuai dan tepat, salah satunya yaitu model pembelajaran tipe STAD. Media film animasi dapat digunakan pada tahap guru menyajikan materi pelajaran, sehingga waktu yang digunakan untuk menyajikan materi juga dapat dipersingkat. Media film animasi dapat memberikan kesan menyenangkan, dan mempermudah mengingat materi pembelajaran. Model pembelajaran kooperatif tipe STAD merupakan salah satu model pembelajaran yang dapat menumbuhkan dan meningkatkan motivasi serta keaktifan siswa dalam proses pembelajaran.

\section{Model pembelajaran kooperatif ini dipilih} karena model pembelajaran tersebut merupakan model pembelajaran yang kegiatan belajar mengajarnya berpusat pada siswa. Pendekatan pembejaran ini akan mendorong siswa akan melakukan kerja sama dalam kegiatannya seperti diskusi atau pengajaran teman sebaya (Suwaningsih, Pasaribu, \& Darsikin, 2017). Model ini berbasis pada teori belajar kognitif dan teori belajar social. Kelebihan dari pembelajaran kooperatif siswa dapat meningkatkan sikap positif yang mengarah pada hasil belajar siswa yang tinggi, sehingga pembelajaran kooperatif terutama tipe STAD dapat membantu siswa dalam proses yang positif, yaitu kerjasama antara teman sebaya sehingga pemahaman terhadap materi akan lebih mudah bila dibandingkan dengan teknik konvensional karena dapat menimbulkan motivasi untuk giat belajar.

\section{METODE PENELITIAN}

Jenis penelitian ini adalah quasi eksperimen, sedangkan pendekatan yang di gunakan yaitu jenis pendekatan kuantitatif. Pendekatan kuantitatif digunakan untuk mendapatkan data berupa nilai atau angka (Sugiyono, 2016). Variabel dalam penelitian ini terdiri atas variabel bebas dan variabel terikat yang dimana variabel bebasnya adalah pembelajaran kooperatif tipe STAD menggunakan media film animasi, sedangkan variabel terikatnya adalah motivasi dan hasil belajar siswa. Populasi dalam penelitian ini adalah seluruh siswa kelas VII, sedangkan sampelnya yaitu siswa kelas VII-A sebagai kelas eksperimen dan siswa kelas VII-B kelas kontrol. Teknik pengambilan sampel dilakukan menggunakan teknik cluster sampling. Penelitian ini dilaksanakan di MTs. Al-Intishor Sekarbela pada bulan Agustus sampai dengan bulan September 2019.

Pada penelitian ini desain yang digunakan adalah nonequivalent control group design. Dalam desain ini diberikan sebanyak 2 kali perlakuan yaitu sebelum dan sesudah pembelajaran. Tes sebelum perlakuan dinamakan pretest dan tes sesudahnya dinamakan posttest (Sugiyono, 2010). Adapun tabel rancangan desain penelitian yaitu, sebagai berikut:

Tabel 1. Desain Penelitian Nonequivalent Control Group Design

\begin{tabular}{cccc}
\hline Kelompok & Pretest & \multicolumn{2}{c}{ Perlakuan 'osttest } \\
\hline Eksperimen & $\mathrm{O}_{1}$ & $\mathrm{X}_{1}$ & $\mathrm{O}_{2}$ \\
& & & \\
Kontrol & $\mathrm{O}_{3}$ & $\mathrm{X}_{2}$ & $\mathrm{O}_{4}$ \\
\hline
\end{tabular}

Keterangan:

$\mathrm{O}_{1}=$ Kelas eksperimen dan kelas kontrol sebelum perlakuan (pretes)

$\mathrm{O}_{2}=$ Kelas eksperimen dan kelas kontrol setelah perlakuan (postes)

$\mathrm{O}_{3}=$ Kelas kontrol sebelum perlakuan (pretes)

$\mathrm{O}_{4}=$ Kelas kontrol setelah perlakuan (postes)

$\mathrm{X}_{1}=$ Pemberian perlakuan dengan model kooperatif tipe STAD

$\mathrm{X}_{2}=$ Pemberian perlakuan dengan pembelajaran konvensional

Instrumen yang digunakan dalam penelitian ini terdiri dari 2 yaitu: 1) Kuesioner atau angket motivasi belajar yang terdiri dari 20 butir pernyataan. 2) Tes subjektif berbentuk pilihan ganda yang terdiri dari 25 butir soal. Instrumen diberikan pada sebelum dan sesudah pembelajaran berlangsung. Sebelum instrumen digunakan, terlebih dahulu uji instrumen, terdiri dari uji validitas soal, reliabilitas sola, taraf kesukaran soal, dan daya pembeda soal.

Tahapan teknik analisa data terdiri dari Uji prasyarat terdiri dari uji normalitas dan homogenitas. Uji hipotesis atau uji-t. Sebelum uji hipotesis dilakukan, data hasil pretest dianalisis menggunakan uji prasyarat untuk melihat perbedaan pengetahuan awal sampel yang diteliti. Berdasarkan hasil uji prasyarat penelitian diketahui bahwa data pretes dari kedua kelompok berdistribusi normal dan homogen. Hal ini dapat menunjukkan bahwa sampel yang diambil memiliki kondisi awal yang relatif sama atau tidak berbeda nyata.

\section{HASIL DAN PEMBAHASAN}

Rata-rata Motivasi Belajar Sebelum dan Sesudah pada Kelas Eksperimen dan Kelas Kontrol disajikan pada grafik di bawah ini: 


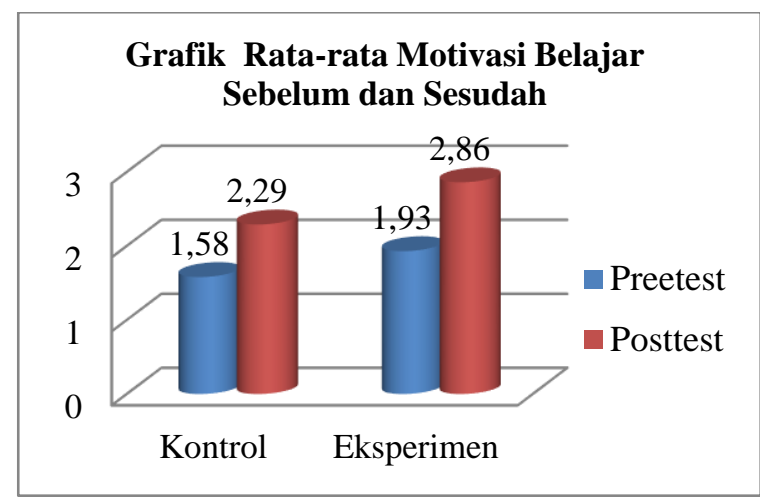

Gambar 1. Rata-rata Motivasi Belajar Sebelum dan Sesudah pada Kelas Eksperimen dan Kelas Kontrol

Gambar 1 menunjukkan motivasi belajar siswa sesudah perlakuan pada kelas eksperimen mengungkapkan 6 orang siswa yang berada di interval 2,50-3,49 dengan kategori motivasi belajarnya cukup baik, 6 orang siswa yang berada di interval 3,50-4,49 dengan kategori baik, dan 3 orang siswa yang berasa di interval 4,50-5,00 dengan kategori motivasi belajarnya sangat baik. Untuk kelas kontrol mengungkapkan 1 orang siswa yang berada di interval 1,50-2,49 dengan kategori motivasi belajarnya kurang baik atau tidak mempunyai motivasi belajar, 7 orang siswa yang berada di interval 2,50-3,49 dengan kategori motivasi belajar cukup baik, dan 6 orang siswa yang berada di interval 3,50-4,49 dengan kategori motivasi belajarnya baik. Dengan demikian kelas eksperimen mempunyai motivasi belajar yang sangat baik jika dibandingkan kelas kontrol. Begitupun untuk motivasi belajar sebelum perlakuan dimana rata-rata kelas eksperimen dan kelas kontrol dikategorikan motivasi belajarnya kurang baik dan cukup baik.

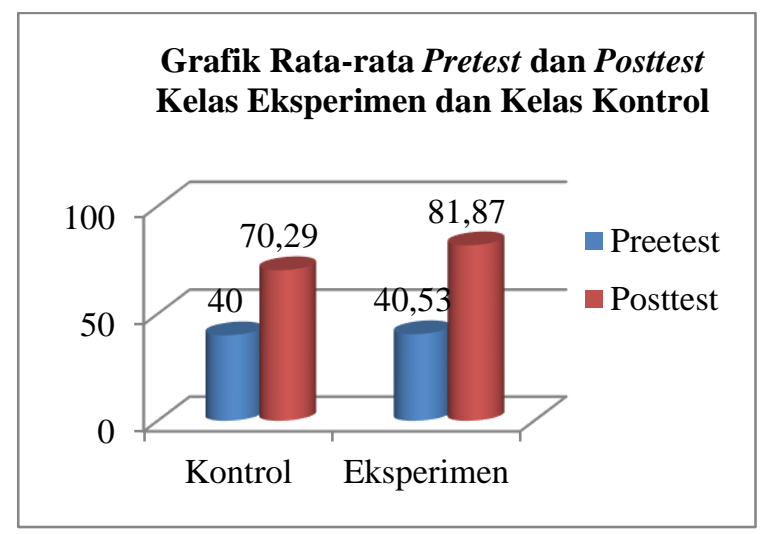

Gambar 2. Nilai Rata-rata Pretest dan Posttest Kelas Eksperimen dan Kelas Kontrol

Gambar 2 Menunjukkan data pretest kelas eksperimen didapatkan nilai rata-rata 40.53 dan rata-rata kelas kontrol dengan nilai
40, sehingga dapat disimpulkan bahwa tidak ada pengaruh antara pretest kelas eksperimen dan kelas kontrol. Nilai posttest kelas eksperimen didapatkan nilai rata-ratanya yaitu 81.87 dan rata-rata kelas kontrol yaitu 70.29. Sehingga dapat disimpulkan bahwa terdapat perbedaan yang signifikan antara rata-rata posttest kelas eksperimen dan kelas kontrol.

Terdapat perbedaan pencapain motivasi dan hasil belajar siswa yang menggunakan model pembelajaran kooperatif tipe STAD menggunakan media film animasi dibandingkan siswa yang menggunakan metode belajar konvensional dapat dilihat dari kategori siswa yang mempunyai motivasi belajar tinggi dengan siswa yang tidak mempunyai motivasi belajar atau motivasi belajarnya rendah. Siswa yang memiliki motivasi belajar yang tinggi yaitu pada siswa yang menggunakan model pembelajaran kooperatif tipe STAD menggunakan media film animasi (eksperimen), sedangkan siswa yang memiliki motivasi belajar yang rendah yaitu pada kelas kontrol atau kelas yang menggunakan model pembelajaran konvensional. Dapat disimpulkan bahwa model pembelajaran kooperatif tipe STAD menggunakan media film animasi dapat mempengaruhi motivasi belajar siswa daripada yang menggunakan model pembelajaran konvensional dengan materi yang sama. Siswa yang memiliki motivasi belajar yang tinggi adalah biasanya siswa sangat antusias terhadap pembelajaran yang bersifat menantang.

Hasil penelitian ini sejalan dengan penelitian yang dilakukan oleh Juni, dkk dimana nilai rata-rata motivasi dan hasil belajar pada kelas yang diberi perlakuan (eksperimen) lebih tinggi dari pada kelas yang tidak diberikan perlakuan (kontrol)(Astrawan, Marhaeni, \& Arnyana, 2013) dan penelitian yang lain dimana hasil penelitian menunjukkan bahwa terdapat pengaruh yang signifikan penerapan model pembelajaran kooperatif tipe STAD berbantuan video animasi terhadap hasil belajar siswa kelas VII SMPLB C Negeri Denpasar (Haryanto, Marhaeni, 2015).

Adanya perbedaan hasil belajar yang diperoleh dapat terjadi karena model pembelajaran kooperatif tipe STAD memiliki kelebihan sebagaimana yang telah dikemukakan oleh Soewarso yang dikutip oleh Bahtiar bahwa pembelajaran kooperatif dapat menghasilkan pencapaian belajar siswa yang tinggi, menambah harga diri siswa dan memperbaiki hubungan dengan teman sebaya. Selain itu pemberian hadiah atau penghargaan dapat memberikan dorongan bagi siswa untuk mencapai hasil yang lebih tinggi (Bahtiar, 2015; Heriyati, 2017). Proses pembelajaran dikatakan 
berhasil jika setidaknya siswa terlibat secara aktif, baik secara fisik, mental, ataupun sosial selama proses pembelajaran. Selain itu, siswa juga harus menunjukkan motivasi atau kegairahan tinggi terhadap pembelajaran yang berlangsung.

Salah satu alternatif yang bertujuan untuk membuat siswa lebih termotivasi dalam belajar fisika adalah dengan menerapkan model pembelajaran kooperatif tipe STAD menggunakan media film animasi, yang dapat meningkatkan hasil belajar siswa. Model pembelajaran kooperatif tipe STAD menggunakan media film animasi sangat baik diterapkan pada pembelajaran fisika. Hal ini disebabkan karena model pembelajaran kooperatif tipe STAD menggunakan media film animasi merupakan model pembelajaran yang dapat merangsang pikiran, perhatian serta minat siswa untuk berpartisipasi aktif dalam kegiatan kelompok, mendorong siswa untuk bekerja secara kooperatif sehingga suatu pekerjaan atau kegiatan dapat diselesaikan dengan cepat, tepat dan mudah.

Penerapan model pembelajaran kooperatif tipe STAD merupakan salah satu model pembelajaran yang dapat memberikan pengalaman langsung yang bersifat konkret dalam belajar kelompok. Selain itu penerapan model pembelajaran kooperatif tipe STAD secara efektif akan berpengaruh pada motivasi belajar siswa yang lebih baik pada proses pembelajaran fisika.

Alasan mengapa media film animasi dipilih dalam penelitian ini yaitu Penggunaan media ini akan membuat subjek lebih tertarik dalam mengikuti pembelajaran. Film animasi juga menggambarkan objek nyata yang dikemas dalam bentuk animasi. Selain itu penggunaan film animasi juga memiliki keunggulan dapat diputar secara berulang sesuai dengan kebutuhan pembelajaran (Aini \& Tresnawati, 2019). Hasil belajar yang di peroleh siswa setelah mengikuti pembelajaran dengan menggunakan media film mengalami peningkatan yang lebih tinggi dibandingkan dengan hasil belajar siswa yang mengikuti pembelajaran tanpa menggunakan media film animasi (Sukiyasa \& Sukoco, 2013).

Penggunaan media film animasi ini membuat siswa lebih termotivasi dan meningkatkan pemahaman materi tentang tata surya, sehingga hasil belajar siswa lebih meningkat. Media film animasi merupakan media yang tepat untuk membantu penyampaian materi dalam pembelajaran tata surya, karena dengan media ini siswa dapat mendengarkan dan mengamati rotasi bumi, revolusi bumi dan mengamati benda-benda langit lainnya (Nurfarida, Bahtiar, 2019).
Berdasarkan hasil penelitian yang telah dilakukan bahwa model pembelajaran kooperatif tipe STAD menggunakan media film animasi mempunyai pengaruh signifikan terhadap motivasi dan hasil belajar, hal ini dapat mengembangkan kreativitas melalui interaksi antar siswa yang berlangsung selama proses belajar mengajar. Selain itu rasa ingin tahu siswa pun meningkat sejalan dengan meningkatnya motivasi belajar mereka.

\section{SIMPULAN DAN SARAN}

Berdasarkan hasil penelitian bahwa uji hipotesis yaitu $t_{\text {hitung }}(9.633)>t_{\text {tabel }}$ (1.703), maka $\mathrm{Ha}$ diterima dan Ho ditolak, maka terdapat pengaruh model pembelajaran kooperatif tipe STAD menggunakan media film animasi terhadap hasil belajar peserta didik. Berdasarkan analisis data motivasi belajar sesudah perlakuan diperoleh rata-rata kelas eksperimen 2.86 dan rata-rata kelas kontrol 2.29 sehingga dapat disimpulkan bahwa ada peningkatan motivasi belajar yang signifikan antara kelas eksperimen yang diterapkan model pembelajaran kooperatif tipe STAD dan kelas kontrol yang diterapkan pembelajaran konvensional, sehingga terdapat pengaruh model pembelajaran kooperatif tipe STAD menggunakan media film animasi terhadap motivasi belajar peserta didik.

Berdasarkan analisis data hasil belajar dan motivasi belajar peserta didik disimpulkan bahwa, terdapat pengaruh model pembelajaran kooperatif tipe STAD menggunakan media film animasi terhadap motivasi dan hasil belajar di MTs. Al-Intishor Sekarbela.

Adapun saran yang diajukan dalam penelitian ini antara lain yaitu, sebaiknya model pembelajaran kooperatif tipe STAD menggunakan media film animasi tidak hanya diterapkan pada materi tata surya saja, tetapi bisa digunakan untuk berbagai materi fisika lainnya. Model pembelajaran kooperatif tipe STAD perlu mendapat perhatian dan tanggapan dari guru, karena melalui pembelajaran kooperatif dapat menghasilkan pencapaian belajar siswa yang tinggi dan memperbaiki hubungan dengan teman sebaya.

\section{DAFTAR RUJUKAN}

Aini, H. Q., \& Tresnawati, D. (2019). Perancangan Media Pembelajaran Interaktif Untuk Anak Autis di Sekolah Luar biasa. Jurnal Algoritma, 16(1), 5157.

Ansori, A. H. (2015). Strategi Peningkatan Sumber Daya Manusia Dalam Pendidikan Islam. Jurnal Qathrunâ, 2(2), 19-56.

Astrawan, I. W. J., Marhaeni, A. A. I. N., \& 
Arnyana, I. B. P. (2013). Pengaruh model pembelajaran kooperatif tipe student team achievement division terhadap motivasi belajar dan hasil belajar IPA. Jurnal Pendidikan Dasar Ganesha, 3(1). Retrieved from

Bahtiar. (2015). Strategi Belajar Mengajar Sains (IPA) (1st ed.). Mataram: Sanabil.

Fujiawati, F. S. (2016). Pemahaman Konsep Kurikulum dan Pembelajaran dengan Peta Konsep Bagi Mahasiswa Pendidikan Seni. Jurnal Pendidikan Dan Kajian Seni, 1(1), 16-28.

Gilang Herjuna, Sanjaya, A. S. (2017). Penerapan Model Pembelajaran Kooperatif Tipe Stad ( Student Teams Achievement Division ) Untuk Meningkatkan Pemahaman Konsep Kimia Siswa Kelas XI IPA 3 SMA Srijaya Negara Palembang. Jurnal Penelitian Pendidikan Kimia: Kajian Hasil Penelitian Pendidikan Kimia, 4(2), 152-162.

Hanna, D., Sutarto, \& Harijanto, A. (2016). Model Pembelajaran Tema Konsep Disertai Media Gambar Pada Pembelajaran Fisika Di Sma. Jurnal Pembelajaran Fisika, 5(1), 23-29.

Haryanto, Marhaeni, S. (2015). Pengaruh Model Pembelajaran Kooperatif Tipe Stad Berbantuan Video Animasi Terhadap Hasil Belajar Ipa Dan Kreativitas Siswa Smplb C Negeri Denpasar. E-Journal Program Pascasarjana Universitas Pendidikan Ganesha, 5(1), 1-8.

Hasanah, U., \& Nulhakim, L. (2015). Pengembangan Media Pembelajaran Film Animasi Sebagai Media Pembelajaran Konsep Fotosintesis. Jurnal Penelitian Dan Pembelajaran IPA, 1(1), 91.

Heriyati, H. (2017). Pengaruh Minat dan Motivasi Belajar Terhadap Prestasi Belajar Matematika. Formatif: Jurnal IImiah Pendidikan MIPA, 7(1), 22-32.

Laela NRK. dan Partono. (2015). Pengaruh Model Pembelajaran Inkuiri Terbimbing Terhadap Hasil Belajar Fisika Siswa Kelas VIII SMP Negeri 4 Metro Semester Genap Tahun Pelajaran 2013/2014. Jurnal Pendidikan Fisika, 3(1), 64-72.

Nurfarida, Bahtiar, N. E. (2019). Pengaruh Model Pembelajaran Inkuiri Terbimbing Pada Pembelajaran Fisika Untuk Meningkatkan Hasil Belajar Siswa. RelativitaS: Jurnal Riset Inovasi Pembelajaran Fisika, 2(1), 9-19.

Palupi, R., Anitah, S., \& Budiyono. (2014).
Hubungan Antara Motivasi Belajar Dan Persepsi Siswa Terhadap Kinerja Guru Dalam Mengelola Kegiatan Belajar Dengan Hasil Belajar Ipa Siswa Kelas VIII Di SMPN N 1 Pacitan. Jurnal Teknologi Pendidikan Dan Pembelajaran, 2(2), 157-170.

Rivai, A. (2019). Penerapan Model Pembelajaran Kooperatif Tipe Stad Untuk Meningkatkan Hasil Belajar Siswa Di Sekolah Dasar. Jurnal Basicedu, 3(4), 115-124.

Sugiyono. (2010). Metode Penelitian Pendidikan Pendekatan Kuantitatif, Kualitatif, dan $R$ \& $D$ (11th ed.). Bandung: Alfabeta.

Sugiyono. (2016). Metode Penelitian Pendidikan Pendekatan Kuantitatif, Kualitatif, dan $R$ \& $D$ (24th ed.). Bandung: Alfabeta.

Sukiyasa, K., \& Sukoco, S. (2013). Pengaruh media animasi terhadap hasil belajar dan motivasi belajar siswa materi sistem kelistrikan otomotif. Jurnal Pendidikan Vokasi, 3(1), 126-137.

Suwaningsih, N., Pasaribu, M., \& Darsikin, D. (2017). Pengaruh Pembelajaran Kooperatif tipe STAD Berbasis Mind Maping terhadap Hasil Belajar Fisika pada Pokok Bahasan Cahaya di SMP Negeri 18 Palu. JPFT (Jurnal Pendidikan Fisika Tadulako Online), 5(2), 19-24.

Zakiah, I., \& Kusmanto, H. (2017). Pengaruh Penerapan Model Pembelajaran Kooperatif Tipe Make a Match Terhadap Kreativitas Siswa Dalam Pembelajaran Matematika. Eduma: Mathematics Education Learning and Teaching, 6(1), 32.

Zakirman, Z., \& Hidayati, H. (2017). Praktikalitas Media Video dan Animasi dalam Pembelajaran Fisika di SMP. Jurnal IImiah Pendidikan Fisika AlBiruni, 6(1), 85-93. 